\title{
ANATOMY AND PHYSIOLOGY OF THE NEWBORN RELATED TO ANAESTHESIA
}

\author{
W. H. Cochrane, M.B., B.CH., F.F.A.R.C.S., D.A.*
}

LIKE ALL RECENT ADVANCES in anaesthesia, the only sound approach to paediatric practice is with an understanding of the basic anatomy and pertaining physiology. From these viewpoints, the child merits separate consideration from the adult. To make the comparison more extreme, it is probably best to think of the newborn baby, because at that age variations from the adult norm will be magnified and more obvious.

Looking at the anatomy of the newborn's respiratory apparatus we find that, unlike the adult whose ribs slope obliquely downwards from the vertebral column, the ribs lie horizontally." This excludes any upswing or bucket handle motion induced by the external intercostals, and so on, and thus there is virtually no costal element in respiration. At the age of one year, the ribs come to acquire the beginnings of obliquity found in adult life, but this change in lie is not completed until the sixth or seventh year. This descent of the ribs is brought about by the rib cage outgrowing the lungs within.

In the newborn the diaphragm lies much lower than in the adult: the right dome reaching T8-9, the left T9-11. This indicates voluminous lung bases, but it must be remembered that respiration is embarrassed because the abdomen is distended by a large liver on the right, and especially after meals by the stomach on the left, while the greater part of the gut is outside the pelvic cavity, which has not yet acquired a capacity proportionate to its size in adult life. Furthermore, shortly after birth the gut begins to contain air and thus increases its volume. Within the chest, the heart and mediastinum, including the rather sizable thymus, take up an undue amount of room. At six months mediastinal structures occupy 43 per cent of the space in the chest while at twelve years the figure is only 33 per cent. This is probably a better indication of lung volume than the cardiothoracic ratio, which in the neonate is normally 0.55 , whereas 0.50 is the upper limit for normality in the adult.

The lung is developed by dichotomous branching of the bronchi initially, and inthe later stages by irregular branching. This process is found to be proceeding actively in premature babies, but even in the normal full-term infant several further branchings may occur until about twenty-four divisions in all are present. Alveolar development is in various stages of maturity, and many are lined by relatively impermeable cuboidal epithelium. ${ }^{2}$

In the adult the dimensions of the trachea approximate $12 \mathrm{~cm}$. in length and 15 to $20 \mathrm{~mm}$. in diameter. For its size the newborn has relatively greater dead space in its bronchial tree, the trachea measuring $4 \mathrm{~cm}$. in length by $4-6 \mathrm{~mm}$. in diameter.

*Royal Alexandra Hospital, Edmonton, Alberta. 
From these facts, it would appear that the baby is ill equipped, respiratorywise, for its separate existence, but from the cardiac viewpoint it can get along more than well enough. Until the moment of birth, the heart has been pumping the blood through the placenta and the body, which adds up to considerably greater work. At birth, by removing the placenta, a large part (25 per cent) of the peripheral resistance has been removed. The proportion of blood between placenta and foetus near term is about 25 per cent placenta, 75 per cent foetus, and if the obstetrician waits for some minutes before clamping the cord-it will usually have ceased pulsating and the baby may gain up to $125 \mathrm{ml}$. of blood, The newborn has about 40 to $50 \mathrm{ml}$. of blood per pound of weight. The heart has to pump only about 80 per cent of the volume present in intrauterine life through 75 per cent of its previous circulatory bed and much less distance. This reduction in cardiac work is reflected in the fact that the heart diminishes in relative size during the first year of life. The foetal pulse rate of 130 to 180 per min. drops to about 140 , an hour after birth, and during the first year, the rate, though variable, averages 110-1:30. Vagal restraint is minimal. Blood pressure is around 75 to $95 \mathrm{~mm}$. systolic in the first few weeks and bears some relationship to birth weight. Right and left ventricular pressures are similar at birth, but exactly when the adult disparity occurs is uncertain. Cardiac output averages a little over $500 \mathrm{ml}$. per min. and the stroke volume therefore $4-5 \mathrm{ml}$. On a weight basis, this cardiac output is roughly twice the adult norm at rest.

Foetal haemoglobin is qualitatively different from the adult type. It has a different oxygen dissociation curve and resists denaturalization by alkalis. At birth there may be $18 \mathrm{gm}$. Hb of foetal type; at four months of age, all the $\mathrm{Hb}$ is of adult character; and at one year of age, $12 \mathrm{gm}$. Hb per cent is a more likely figure for the healthy child. The significance of foetal $\mathrm{Hb}$ is that the oxygen dissociation curve is shifted to the left, which means that it aids the infant by being more readily saturated at low oxygen tensions and while being more acid assists oxygen dissociation. In other words, the baby's blood takes up oxygen more easily and he can make better use of it. Incomplete alveolar development and thick alveolar walls impede gaseous exchange. Carbon dioxide, being more readily diffusible, enters the alveolus more easily than oxygen is taken up. Any newborn child, if observed long enough, will show episodes of periodic breathing. These can be abolished by placing him in an atmosphere rich in oxygen., ${ }^{4,5}$ That carbon dioxide plays a relatively unimportant role in effecting respiratory control is generally accepted and, indeed, it is considered that, in the infant, oxygen lack is the fundamental factor in the regulation of breathing.

Most workers agree that the average tidal volume is around $16-20 \mathrm{ml}$. for a full-term baby, but in prematures it may be much less. During vigorous crying, tidal volumes around $160 \mathrm{ml}$. have been noted. Respiratory rate is variable, the average probably being around 40 per min. in the first few days, but the normal may range to 100 or more. As a result of the unfinished lung development, the alveolar area available for respiratory exchange is small. The alveolar area per $\mathrm{ml}$. of total lung volume is half that of adult.lung, while the respiratory surface per $\mathrm{kg}$. of body weight is about one-third that found in the adult. ${ }^{6}$ This requires that one consider what the infant's oxygen needs should be, and here again the 
figures are heavily weighted in favour of the adult. At maturity, oxygen consumption has been established to be around $3.6 \mathrm{ml}$. per $\mathrm{kg}$., or $266 \mathrm{ml}$. per min. for a $70-\mathrm{kg}$. man. In the newborn, the oxygen requirement is around $6-7 \mathrm{ml}$. per $\mathrm{kg}$. or $21-25 \mathrm{ml}$. per min. for a $3 \frac{1}{2} \mathrm{~kg}$. baby. Oxygen requirement is even greater when compared to weight during the age range up to three years. It is also interesting to note that the oxygen needs of the full-term foetus in utero is about $1.25 \mathrm{ml}$. per $\mathrm{kg}$. per min. and $1.5 \mathrm{ml}$. per $\mathrm{kg}$. immediately it is born, while the figure of $b-i \mathrm{ml}$. just mentioned is that of the baby who has becone adjusted to his new independent existence. This tremendous increase in oxygen requirement, some 400 per cent, is in all probability largely due to the oxygen needs necessitated by the work of respiration itself. It has been suggested that respiration in the resting adult requires about 10 per cent of the oxygen consumption, but in the baby it is possible that 40 per cent may not be too high an estimate. Finally, considering a $3 \frac{1}{2}-\mathrm{kg}$. baby and a $70 \mathrm{~kg}$. man, on a weight basis it will be apparent that the baby's tidal volume would be around $500 \mathrm{ml}$. with a minute volume of some $16,000 \mathrm{ml}$., roughly twice that of the adult.

In the neonate, dead space is relatively greater than in later life, but to some extent the tracheobronchial tree quickly adapts during grow th to overcome this inadequacy. For example; the cross-section of the trachea at birth per unit of lung volume is twice the value of this ratio at the age of one year. On the other hand, the small lumen of the trachea imposes enormous effort on the respiratory musculature. The saggital diameter of the infant's trachea is roughly one-fourth or one-fifth that of the adult. It follows from this, that if the physical laws governing gas flow through the trachea obey Pouiseuille's Law, which states that the volume of fluid flowing through a tube of given length varies as the fourth power of the diameter of the tube, any increase in the rate of gas flow would produce an effect on the resistance to respiration of $4^{4}$ or 256 times that caused by the same increase in flow rate in the adult. The length of the trachea has a less marked effect to benefit the infant. That this physical law has tremendous importance will be obvious to anyone who has seen a child with croup.

I would now like to quote Dr. Ralph Waters, who in 1942 said "in anaesthesia it may be desirable to relieve a weak patient of the energy output necessary to contract the diaphragm and intercostal muscles." I do not think he had children especially in mind when he made this remark, but there can be few aspects of the anaesthetist's practice today where the use of controlled respiration is more generally desirable or more rewarding. Perhaps it should even be the routine method in paediatric work. It requires much greater skill, is exacting in the demands it makes of the anaesthetist, but gives definite advantages to patient and surgeon.

Traditionally, open drop ether has been held to be an excellent method for paediatric anaesthesia, but its drawbacks are many. To begin with, there is the difficulty of inducing and maintaining a reasonable depth of anaesthesia. This is a function of the small tidal volume of the child and the difficulty of vapourizing ether from the mask. The heat necessary for the vapourization of the ether has to come from the anaesthetist's hands and from the atmosphere with the result that it is difficult to prevent condensation of water vapour and ice formation 
on the mask, and the child inhales a cold dry mixture of gases. The oxygen tension in this inspired mixture is also somewhat diminished and further reduced at alveolar level where the tension of water vapour is again elevated. The fact that ether at reasonable levels of anaesthesia stimulates respiration reflexly is its greatest safeguard, but this can be very distressing to the surgeon as the overactive diaphragm tends to keep pushing the intestines into the wound. Even at light levels of anaesthesia, hypercarbia is probably present as carbon dioxide elimination with the semi-open mask technique must necessarily be impaired. Good relaxation of the abdomen with this technique can only be obtained by the use of deep levels of anaesthesia associated with respiratory depression and its attendant hazards.

Today, very light levels of general anaesthesia in combination with muscle relaxants and controlled respiration has become the basic method of anaesthesia in most centres for adult patients. I would suggest that with this experience behind us we should now apply it generally in paediatric work where its results are even more rewarding. Due to the immature state of the neuromuscular junction in the baby, reaction to the endotracheal tube is minimal. It can only cause some irregularity of respiration in the neonate who cannot even lift his head off the pillow before he is three months old. Remembering that the larynx is placed rather higher in the neck relative to the cervical vertebrae and that for the first $\mathrm{cm}$. it inclines anteriorly, intubation becomes relatively easy with a little practice. The largest tube that will pass easily should be used and without a wire stilette protruding. With good tubes a stilette should never be required. Stabilization of the tube after insertion with a small saline-moistened pack prevents it slipping out of the larynx and prevents it being shaken about, thus preventing laryngeal trauma. Controlled respiration being the objective, there is a choice of various anaesthetic circuits and systems available. A variety of infant circle systems are available. There is the Water's cannister, the Rees' modification of the Ayre's T-tube, and a choice of unidirectional valves which permit the use of positive pressure respiration. Circle equipment is of ten only a miniaturized adult outfit and dead space is too great. Three or four ml. increase in dead space is quite significant to a small premature baby whose tidal volume is normally only $5-10 \mathrm{ml}$. Apart from that, resistance in many circle systems tends to be significant, especially when the directional valves get moist. The Water's cannister is also difficult to construct with elimination of dead space, and it is even more difficult to attach conveniently to a small child. The Rees' system is to all intents and purposes a simple Ayre's T-tube some ten inches long with a small-open ended $500-\mathrm{ml}$. bag attached distally. Ventilation is carried out by compression of the bag, the end orifice being simultaneously closed with the thumb of the opposite hand. Dead space in this system is the volume of the connection between the side inlet and the endotracheal adaptor and need be no more than one or two $\mathrm{ml}$. A further advantage is its simplicity and the ease with which it can be constructed. Resistance to expiration is minimal, as the system is open to the air. Carbon dioxide elimination is effective provided the rate of gas flow approximates to three times the minute volume, which does not dernand excessive flow rates in the young. Unidirectional non-rebreathing valves have 
much to offer, but seem to be at a disadvantage at present due to their appreciable dead space and the fact that most are rather clumsy and tend to get badly in the way during surgery, such as that for cleft palate.

The technique of intermittent positive pressure respiration advocated by Rees has been employed by the author in several hundred cases, while its use by the originator and his associates and close followers must amount to many tens of thousands of patients. To date there have been no reports of interstitial emphysema as a major complication. The claim that I.P.P.R. is fraught with the danger of interstitial emphysema is probably unjustified, unless the bronchial anatomy is defective, and then the child may produce the damage spontaneously. Negative and positive pressures of $40-50 \mathrm{~cm}$. of water can easily be :produced by the child, and are much more than the anaesthetist would wish to use. ${ }^{7}$ These very high intrathoracic pressures are explained by another basic. law of physics which says that the pressure difference between the two sides of a spherical membrane in tension is for any given degree of tension inversely proportional to the diameter of the sphere. In the child it is the small diameter of the diaphragm which gives the answer, but it is perhaps worth remembering that it is always desirable to suit the size of the bag on the anaesthetic apparatus to the size of the patient and so to ventilate more effectively with less effort.

As a response to trauma there is, in the neonate as in the adult, a loss of $\mathrm{K}^{+}$and $\mathrm{N}^{++}$, but in the adult the $\mathrm{K} / \mathrm{N}$ ratio is greater than the normal ratio in which these elements exist in normal tissue. This indicates a breakdown of tissue, and additionally a loss of $\mathrm{K}^{+}$from tissues where the $\mathrm{N}^{++}$is preserved. In the neonate, on the other hand, the $\mathrm{K} / \mathrm{N}$ ratio approximates that found in lean muscle, indicating cellular breakdown without extra loss of $\mathrm{K}^{+}$frorì other cells. ${ }^{8}$ We know that the infant under three months of age is sensitive to the anti-depolarizing relaxants which depress ionic migration, but he is relatively resistant to the depolarizing drugs like suxamethonium which result in ionic transfer. It is postulated that this variation from the adult type of response may stem from the infant's resistance to intracellular $\mathrm{K}^{+}$loss, in response to the hormonall effects of trauma. Alternatively, as in the myasthenic patient, a circulating curariform agent may be responsible. ${ }^{9,10}$ This is not altogether impossible in view of the size of the thymus. At any rate, for practical purposes the relaxant of choice where one is needed would appear to be suxamethonium, in most circumstances. Though relatively resistant on the basis of weight to suxamethonium, the total dose should be kept as low as possible. This may cause difficulty, as the total amount of fluid to be given may require the use of fairly concentrated solution with the attendant problem of measuring small doses. As a result of the fact that suxamethonium is destroyed enzymatically and in an exponential fashion, the total dosage needed increases enormously when given intermittently leading to greater likelihood of a dual response with change of end-plate function.

It is well known that during anaesthesia infants tend to become hypothermic. In the very young this carries with it the danger, albeit a small one, of sclerema. But while a small temperature drop may not be deleterious and possibly quite advantageous, it is desirable in cases undergoing prolonged major surgery to 
keep a check on the temperature and have the baby lying on a controllable heating pad. This tendency towards a drop in temperature is a function of the child's immature heat-regulating mechanism and his very large relative surface area. Older children, on the other hand, tend to become hyperthermic during the more conventional anaesthetic with spontaneous respiration. This hyperthermia may well have some association with so-called ether convulsions by helping to trigger off an already susceptible central nervous system. The use 0 f controlled respiration, on the other hand, avoids this hazard. With the elimination of the muscular effort of breathing and the associated heat production of muscular contraction, body temperature tends to drop. Advantage has been taken of this fact in the treatment of salicylate poisoning in children, when treatment is directed at the symptom of hyperpnoea. ${ }^{11}$ Prolonged curarization and controlled respiration allows the temperature to return to normal levels, and the child is tided over the crisis until excretion has removed a large part of the poison.

- During the first few days of life, the infant loses some 10 per cent of body weight. Losses up to 20 per cent occur occasionally and are not usually harmful, Nursing in an atmosphere approaching 100 per cent humidity and preferably about $85^{\circ} \mathrm{F}$. halves the estimated insensible fluid loss which becomes roughly $14 \mathrm{ml}$. per $\mathrm{kg}$. per day. If the child is not initially dehydrated, he can be left without fluids for two or three days. Subsequent to surgery, Rickham recom. mends only $5 \mathrm{ml}$. per hour of $1 / 5 \mathrm{~N}$ saline for the first two days (that is, $120 \mathrm{ml}$. per day) and $10 \mathrm{ml}$. per hour on subsequent days. These amounts are for full. term infants, and in premature infants the infusion would be reduced. The basic infusion fluid in babies is $1 / 5 \mathrm{~N}$ saline in glucose water, as the kidneys in the ver! young have difficulty in excreting salt. Potassium loss is minimal and is disregarded, except in the presence of prolonged gastric suction, which, if continued for three days or more, requires the daily administration of $60 \mathrm{ml}$. of Darrow's solution. ${ }^{12}$

An aspect of postoperative care is the desirability of nursing the patient in the head-up posture if at all possible, laying him on his side and turning hin at least three-hourly. Aspiration of vomit is not a problem in the lateral position, and the child's respiration is facilitated. Atelectasis, if it occurs, invariably starts in the poorly-aerated upper lobes and spreads from there. It is worth noting that the bronchi of the upper lobes run almost directly backwards in the infant. The treatment of atelectasis should include hourly percussion with the finger-tips, and nursing with the affected side uppermost. This is often effective, but if it fails suction of the tracheobronehial tree with a fine rubber catheter is of ten efficacious, especially when the right side is affected. Left-sided involyement not infrequently requires brorrchoscopy however, and this may have to be repeated.

\section{SUMMARY}

Emphasis is laid on anatomical and physiological differences that exist between the child and the adult, with special regard as to how these variations may in. fluence the anaesthetist in his management of paediatric cases. It is suggested 
that the adoption of a method involving the use of light general anaesthesia, intermittent positive pressure respiration, and, when necessary, muscle relaxants should overcome some of the disadvantages of techniques involving deeper levels of anaesthesia and spontaneous respiration. Differences in the infant's response to the muscle relaxant drugs and suggestions on fluid therapy are briefly indicated.

\section{ACKNOWLEDGMENT}

I am particularly grateful to Dr. J. W. Dundee, Senior Lecturer in Anaesthesia at the Queen's University of Belfast, for help in the preparation of this paper and to Dr. G. Jackson Rees of the Department of Anaesthesia of the University of Liverpool upon whose instruction in paediatric anaesthesia this paper is largely founded.

\section{RÉSUMÉ}

L'on a démontré que, en comparaison de l'adulte, l'enfant et plus particulièrement le nouveau-né possède une réserve respiratoire considérablement réduite. Cela est dû, d'une part, à une surface relative beaucoup plus petite des alvéoles respiratoires et à leur développement incomplet si on les compare au poids corporel et, d'autre part, à un besoin d'oxygène beaucoup plus grand. Le travail de la respiration, on l'a démontré, est également plus considérable; cela est dâ au rythme plus rapide de la respiration, à la résistance au courant d'air à travers une petite trachée et à sa dépendance de la contraction diaphragmatique. Chez le nouveau-né, l'influence essentielle que régit la respiration est plutôt le manque d'oxygène que l'excédent de $\mathrm{CO}_{2}$. Employer, chez les ẻnfants, les méthodes conventionnelles d'anesthésie, c'est-à-dire la respiration spontanée et ce l'anesthésie profonde requise parfois pour certaines opérations, est une chose condamnable et nous sommes d'avis qu'il serait préférable de soulager l'enfant de l'effort qu'il doit faire pour respirer en employant une technique incluant une respiration à pression positive intermittente, une anesthésie générale légère et, sị les circonstances l'exigent, l'usage de myorésolutifs. Chez le nouvedu-né, le suxamethonium semble être le médicament de choix. Comme liquide à administrer, un mélange de $1 / 5$ de solution salée et glucosée isotonique semble l'idéal à cause de l'immaturité des reins et de leur difficulté d'excréter le sel. Au cours des deux premiers jours post-opératoires, nous ne conseillons pas de donner plus de $120 \mathrm{ml}$ par jour de ce mélange et, par la suite, $240 \mathrm{ml}$ par jour. On ne porte pas attention au remplacement du potassium, excepté chez les malades qui ont une aspiration gastrique prolongée. On doit nourrir ces malades en leur maintenant la tête élevée et les tourner régulièrement sur un côté et sur l'autre et, de préfêrence, dans une atmosphère à $85^{\circ} \mathrm{F}$. et contenant $100 \%$ d'humidité.

\section{REFERENCES}

1. ReEs, G. Jackson. Neonatal Anaesthesia. Brit. Med. Bull. 14 (1958).

2. Patren, B. M. Human Embryology. 1st ed. London: Churchill (1950).

3. Surth, C. A. The Physiology of the Newborn Infant. 2nd ed. Springfield: Thomas (1953). 
4. Wilson, J. L., Long, S. B., \& Howard, P. Respiration of Premature Infants, Response to Variations of $\mathrm{O}_{2}$ and to Increased $\mathrm{CO}_{2}$ in Inspired Air. Am. J. Dis. Children 68: 1080 (1947).

5. Howard, P. J., \& Bauer, A. R. Irregularities in Breathing in the Newborn Period. Am. J. Dis. Children $77: 592$ (1949).

6. ReEs, G. JAckson. Anaesthesia in the Newborn. Brit. Med. J. $i i: 1419$ (1950)

7. Rees, G. Jackson. Neonatal Respiration, Brit. J. Anaesth. 26: 154 (1954).

8. Rickram, P. P. The Metabolic Response to Neonatal Surgery. 1st ed. London: Oxford University Press (1957).

9. Rees, G. Jachson. Neonatal Anaesthesia Brit. Med. Bull. 14 (1958).

10. Stead, A. L. Response of Newborn Infart to Muscle Relaxants. Brit. J. Anaesth. 27: 124 (1955).

11. Freir, S.; NeAL, B. W.; Nisbet, H. I. A. i Rees, G. J.; \& Wilson, F. Salicylate Intoxica. tion Treated with Intermittent Positive Pressure Respiration. Brit. Med. J. i: 1333 (1957).

12. Ricknam, P. P. The Metabolic Response to Neonatal Surgery. 1st ed. London: Oxford Univérsity Press (1957). 